\title{
COMPLIANCE WITH DIETARY RECOMMENDATIONS IN THE POPULATION OF GENEVA, SWITZERLAND: A TEN-YEAR TREND STUDY (1999-2009)
}

\section{Pedro Marques-Vidal $^{1}$, Daisy de Abreu ${ }^{1}$, Jean-Michel Gaspoz ${ }^{2}$ and Idris Guessous ${ }^{2}$}

${ }^{1}$ Institute of Social and Preventive Medicine (IUMSP), Faculty of Biology and Medicine, University of Lausanne, Switzerland

2 University Hospital of Geneva, Geneva, Switzerland

\section{Aim}

To assess the trends in compliance with dietary recommendations in the Geneva population for period 1999-2009.

\section{Conclusion}

Few improvements were noted in adherence to dietary recommendations in the Geneva population between 1999 and 2009. The low ad decreasing prevalence of adequate calcium and iron intake are of concern. Hence, nutritional information campaigns need to focus on the recommendations that are poorly implemented.

\section{Methods}

Sampling: The sampling methodology of the Bus Santé Geneva study was used.

Dietary intake and dietary recommendations: Dietary intake was assessed using the Food Frequency Questionnaire (FFQ). Dietary recommendations by the Swiss Society of Nutrition for nutrient intake were used to assess compliance.

Data collection: Educational level was divided into primary school and higher than primary school. Nationalities were divided into Swiss and not Swiss. Height and weight were measured and body mass index (BMI) calculated in $\mathrm{kg} / \mathrm{m}^{2}$. Overweight was defined if BMI $\geq 25$ and $<$ $30 \mathrm{~kg} / \mathrm{m}^{2}$; obesity was defined as BMI $\geq 30 \mathrm{~kg} / \mathrm{m}^{2}$.

Statistical analysis: two steps: 1) using the whole sample and 2) excluding participants with values below the $5^{\text {th }}$ or above the $95^{\text {th }}$ percentile of energy intake. Bivariate analyses were conducted using chi-square or analysis of variance. Trends in compliance for dietary intake recommendations were assessed separately for each gender by logistic regression adjusting for age, smoking stats, education and nationality, using survey year as the independent variable

Results

9320 participants aged 35 to 75 years (50\% women)

No significant changes were found for carbohydrate, fat and protein consumption during the 1999-2009 study period, albeit a significant decrease was found in compliance regarding MUFA intake for men. The percentage of participants with a cholesterol consumption $<300$ $\mathrm{mg} /$ day increased in both genders. Consumption of calcium $>1 \mathrm{~g} /$ day and of iron $>15 \mathrm{mg} / \mathrm{day}$ for women and $10 \mathrm{mg} / \mathrm{day}$ for men decreased in both genders. No significant changes were found for vitamin A and D intake, while adequate beta-carotene intake increased in both genders.

\begin{tabular}{|c|c|c|c|c|c|c|}
\hline & \multicolumn{2}{|c|}{ Men $(n=4661)$} & \multicolumn{4}{|c|}{ Women $(n=4659)$} \\
\hline & 1999 & 2009 & & 1999 & 2009 & \\
\hline & $\%$ & $\%$ & $\mathrm{p}^{\text {-value }} \mathrm{a}^{\mathrm{a}}$ & $\%$ & $\%$ & $\mathrm{p}^{\text {-value }}{ }^{\mathrm{a}}$ \\
\hline Total energy $1800-2500 \mathrm{kcal} /$ day & 39.4 & 38.7 & 0.62 & 28.5 & 27.8 & 0.02 \\
\hline \multicolumn{7}{|l|}{ Macronutrients } \\
\hline Carbohydrates $>50 \%$ TEI & 25.1 & 28.9 & 0.11 & 32.1 & 35.7 & 0.07 \\
\hline Protein $<20 \%$ TEI & 93 & 91.2 & 0.12 & 90.5 & 90.5 & 0.84 \\
\hline Total fat $<30 \%$ TEI & 27.6 & 28.7 & 0.6 & 23.1 & 25.6 & 0.12 \\
\hline SFA $<10 \%$ TEI & 18.4 & 22 & 0.34 & 23.2 & 26 & 0.04 \\
\hline MUFA $>10 \%$ TEI & 85.7 & 85.4 & 0.46 & 90.1 & 88.6 & 0.4 \\
\hline PUFA $>10 \%$ TEI & 2.3 & 1.4 & 0.1 & 2.2 & 1.5 & 0.48 \\
\hline \multicolumn{7}{|l|}{ Other nutrients } \\
\hline Cholesterol $<300$ mg/day & 39.7 & 43.1 & 0.01 & 59.6 & 64.1 & 0.02 \\
\hline Fibre $>30$ g/day & 10 & 9.4 & 0.35 & 10.8 & 7.1 & 0.17 \\
\hline Calcium $>1$ g/day & 55 & 48.1 & $<0.001$ & 46 & 38.5 & $<0.001$ \\
\hline Iron $>15$ or $10 \mathrm{mg} /$ day & 68.3 & 65.3 & $<0.001$ & 13.3 & 8.4 & 0 \\
\hline Vitamin $\mathrm{D}>5 \mu \mathrm{g} /$ day & 11.5 & 12.4 & 0.39 & 11 & 11.2 & 0.86 \\
\hline Vitamin $A>800$ or $1000 \mu$ g/day & 31.7 & 30.1 & 0.44 & 37.7 & 40.1 & 0.56 \\
\hline Carotene $>2$ mg/day & 72.6 & 74.2 & 0.38 & 75.7 & 81.5 & 0.03 \\
\hline
\end{tabular}

